\title{
ECOLOGICAL ROLES OF COMMERCIAL MANGROVE PLANTATION FORESTS FOR BENTHIC MACROINVERTEBRATE COMMUNITIES IN THAILAND
}

\author{
CHOOSAK, S. ${ }^{1}-$ THONGJOO, C. $^{2}-$ CHAICHANA, . $^{* 1}$ \\ ${ }^{1}$ Department of Environmental Technology and Management \\ Faculty of Environment, Kasetsart University, Bangkhean Campus, Bangkok, Thailand \\ (phone:+662-579-3878) \\ ${ }^{2}$ Department of Soil Science, Faculty of Agriculture at Kamphaeng Saen, Kasetsart \\ University, Kamphaeng Saen Campus, Nakhon Pathom, Thailand \\ (phone:+663-428-1082) \\ *Corresponding author \\ e-mail:fscircc@ku.ac.th
}

(Received $8^{\text {th }}$ Oct 2015; accepted $5^{\text {th }}$ Mar 2016)

\begin{abstract}
Mangrove plantation for renewable energy production has an important economic value for Thai inhabitants. Planted mangroves may also serve as valuable areas for biodiversity. We aimed to investigate benthic community structure and estuarine environment in mangrove plantation sites (young, intermediate, mature sites and a semi natural mangrove forest) in Samut Songkram province. The mangrove plantation is a monoculture of Rhizophora apiculata compared with a semi natural mangrove forest where 5 species of trees were recorded. Values of mangrove height and diameter at breast height (DBH) increased with the age of the mangrove plantation forests. Overall, the parameters reflected good water quality conditions (temperature 30.75-32 ${ }^{\circ} \mathrm{C}$; $\mathrm{pH}$ 6.69-7.73; salinity 16.33-21.66 ppt; DO 3.45-4.57 mg/l). Nutrient concentrations and BOD were rather low indicating less impact from nutrient sources. In term of biodiversity, phytoplankton and zooplankton appeared to be greater in younger mangrove plantation sites. Intertidal benthic macroinvertebrate communities tended to increase with the age of the plantation site and invertebrate assemblages have developed through time. Hence, it could be stated that mangrove plantation used as charcoal production not only generates income for the local people but also plays an important role in estuarine ecosystems as the crucial habitat for benthic macroinvertebrate species.
\end{abstract}

Keywords: mangrove, biodiversity, water quality, Thailand

\section{Introduction}

The expansion of extensive shrimp farming along coastal areas of Thailand has substantially reduced the extent of mangrove forests. For example, it was reported that mangrove losses attributable to shrimp aquaculture expansion are estimated to be up to $32 \%$ of the total mangrove area destroyed in 1993 (Dierberg and Kiattisimkul, 1996). Losses of mangrove forests have had a huge impact on a broad range of coastal ecosystems and aquatic resources that have declined (Primavera, 1993). In fact, mangrove forests play a key role in ecosystems as well as providing goods and services to humans (Kaplowitz, 2001; Vo et al., 2012). Mangroves provide food sources for marine animals and act as shelter and a nursery ground for fish larvae and other important economic aquatic species such as sea bass, grouper, crab and shrimp (Ronnback, 1999; Kathiresan, 2010). Mangrove trees also help nourish soil organic matter, recycle nutrients and protect shoreline from erosion and tsunamis (Wafar et al., 1997; Osti et al., 2008; Kathiresan, 2012). In terms of the economy, mangroves can be used as a renewable resource for charcoal production that generates income for local inhabitants (Bandaranayake, 1998; Kridiborworn et al., 2012). 
During the past decades, shrimp farming in Thailand has been experiencing outbreaks of viral diseases such as white spot syndrome and reduced shrimp production due to degradation of the environment (Flegel, 1997; Chayaburakul et al., 2004). Disease damage has been extensive, covering large areas of culture and many shrimp farms were abandoned (Dierberg and Kiattisimkul, 1996). As a result, farmers have realized the ecological importance of mangrove forests and have rehabilitated the abandoned areas. Commercial mangrove plantation for charcoal production is also an alternative for local people instead of continuing shrimp culture. It was reported that after the failure of shrimp farming, some locals turned to mangrove plantation as a source of income (Kridiborworn et al., 2012).

In Thailand, local communities have commercially used plantation mangrove forests for sustainable wood extraction for charcoal production for more than 50 years such as in Yeesarn village of Samut Songkhram province (Tontaweewong, 2000). Mangrove plantation is considered sustainable and does not result in a reduction in the area of mangrove forest since the planted mangrove areas that are cut for charcoal production equal the areas where new mangrove forests are planted (Kridiborworn et al., 2012). Mangrove plantation for charcoal production not only provides local venture benefits but also supports and brings back biodiversity. It usually takes approximately 10-15 years before the planted forests reach the mature stage and can be used for charcoal production (Kridiborworn et al., 2012). During this period, planted mangrove forests can provide habitat for aquatic flora and fauna that help to maintain the overall biodiversity of the area despite the fact that the species richness and abundances of coastal fauna may vary in comparison with undisturbed mangrove forest areas (Macintosh et al., 2012; Andradi-Brown et al., 2013).

Therefore, this research aimed to compare the mangrove community and structure of planted and natural mangrove forests. We also determined and compared properties of water and biological resources between the mangrove planted area over time (different years of plantation) and natural mangrove areas at the village of Yeesarn, Samut Songkhram province. In particular, we studied benthic macroinvertebrate communities that may differ among mangrove sites. The results of this study showed the importance of planted mangrove forests as habitats for biodiversity apart from being renewable sources of alternative energy. It also gave us insight into the environmental conditions and variation of biodiversity in the mangrove forests planted in different years.

\section{Materials and Methods}

\section{Study site and charcoal production in Yeesarn}

Yeesarn village $\left(13^{\circ} 18^{\prime} 14.3^{\prime \prime} \mathrm{N} 99^{\circ} 54^{\prime} 07.2^{\prime \prime} \mathrm{E}\right)$ is located in the coastal zone of Amphawa district, Samut Songkhram province and is known as a source of good quality charcoal production (Fig. 1). In fact, Yeesarn village is the first community in Thailand that planted and used mangrove forests for energy production (Chaiyasarn, 2007). Rhizopihora apiculata is the main mangrove species used for making charcoal in this area. The estimated total plantation area of R. apiculata was 2,000 ha and almost $40 \%$ (300 out of 716) of households in Yeesarn were involved in mangrove plantations for charcoal production purpose in a 2010 survey (Kridiborworn et al., 2012). In 1 ha of mangrove plantation, there are around 6,875 trees planted. The rotation period is between 10-15 years with an average wood diameter of 5-8 cm (Chaiyasarn, 2007; Kridiborworn et al., 2012). 


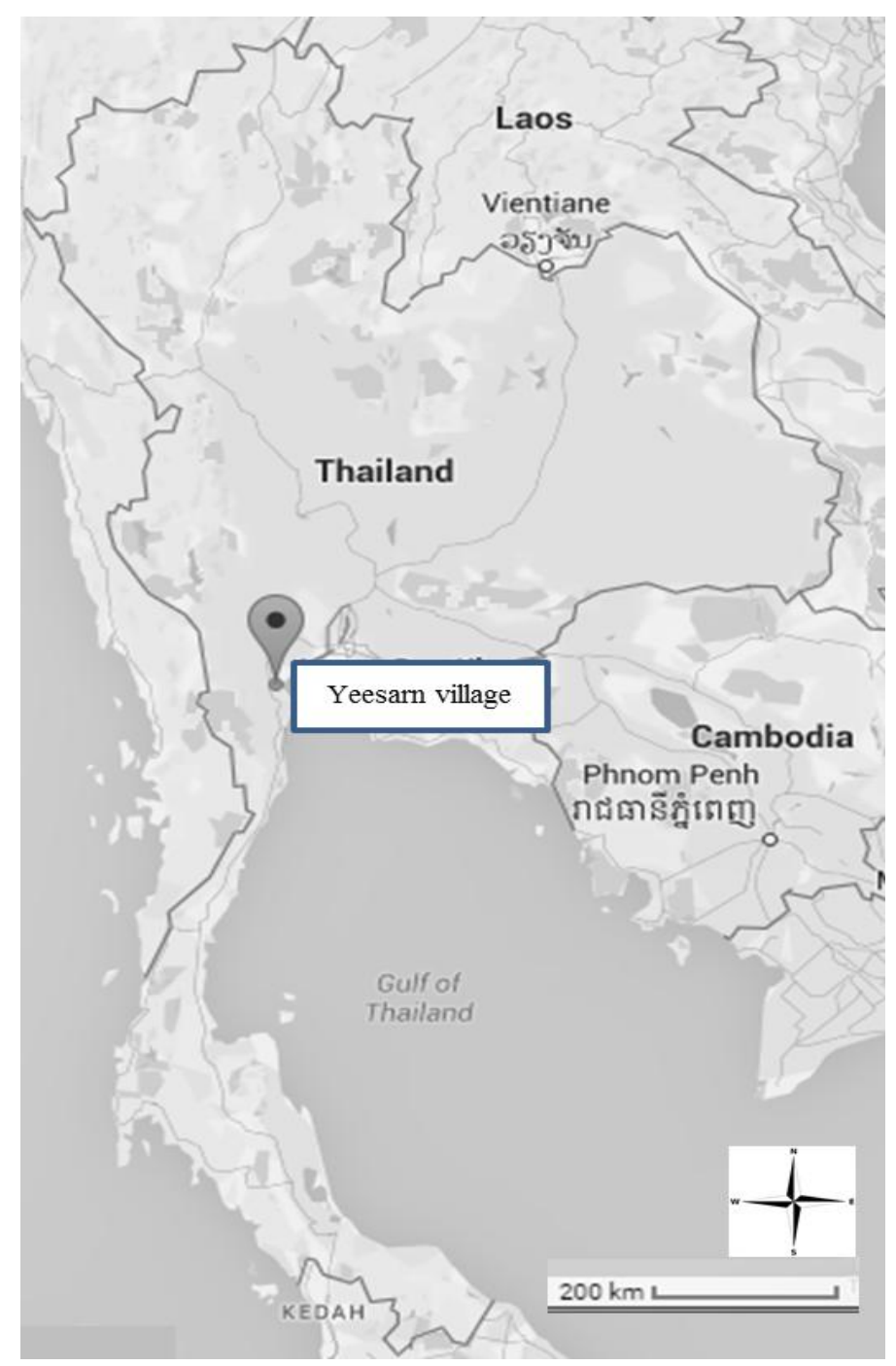

Figure 1. Yeesarn village located in Amphawa district, Samut Songkhram province. Source: www.google.co.th/maps

\section{Mangrove community structure and diversity}

This study compared the mangrove structure, water quality and biodiversity among 3 mangrove plantation sites used for charcoal production and a semi natural forest area with similar environmental conditions. Sampling took place in October 2014 in 3 ages of planted mangrove forests (young aged 0-5 years, intermediate aged 5-10 years and mature aged 10-15 years) and also took place in the semi natural mangrove forest. The semi natural mangrove forest actually used to be a plantation of Rhizopihora apiculata and was left unmanaged. Subsequently the local owner donated the land for conservation purposes. Each site covered an area of around 1.6 ha and in total, there were 4 sites studied. The assessment of each mangrove community structure was conducted randomly using a $3 \times 3 \mathrm{~m}^{2}$ rope plot at each mangrove site. All vegetation present in each quadrat was identified to the species level and the number of individuals was counted. In each plot, a client manometer (clinometer) was used to measure the height of 5 random trees (m) and in addition, the diameter $(\mathrm{cm})(\mathrm{DBH}$ or diameter at breast height) was also recorded using a tape measure. 


\section{Water sampling}

Water quality was determined in a narrow, tidal, man-made creek dredged through each site (6 replicates). These creeks are made and used specifically for transporting cut wood after harvest. We measured water depth (m), transparency (using a Secchi disc; $\mathrm{m}$ ), water temperature $\left({ }^{\circ} \mathrm{C}\right)$ and salinity (refractometer: ppt) on site. A portable multi-meter (Consort 933) was also used to study $\mathrm{pH}$, conductivity $(\mathrm{mS} / \mathrm{cm})$, total dissolved solid (TDS; $\mathrm{mg} / \mathrm{l}$ ) and dissolved oxygen (DO; $\mathrm{mg} / \mathrm{l})$. In addition, 2 bottles of water samples ( 2 1) were collected at about $30 \mathrm{~cm}$ below water surface and transferred to a plastic bottle. One bottle of water was used for analysis of total suspended solid (TSS; mg/l), biochemical oxygen demand (BOD; mg/l) and chlorophyll a $(\mathrm{mg} / \mathrm{l})$. Another bottle of water sample was preserved by adding a few drops of concentrated sulfuric acid until the $\mathrm{pH}$ was lower than 2 and kept in a plastic container (temperature below $4{ }^{\circ} \mathrm{C}$ ) for further analysis (total nitrogen (TN; mg/l), total phosphorus (TP; mg/l), based on standard methods at the laboratory of the Department of Environmental Technology and Management, Kasetsart University and the Central Lab Company.

\section{Biodiversity sampling}

We studied the species composition and abundances of phytoplankton and zooplankton by pouring 51 of water through a plankton net with mesh sizes of 20 and 64 $\mu \mathrm{m}$, respectively. Samples were then transferred to a plastic bottle and preserved with $70 \%$ ethanol. Identification and the number of phytoplankton and zooplankton were studied under a light microscope at the Department of Fishery Biology, Faculty of Fisheries, Kasetsart University. Six replicates were studied.

We used 2 methods to study macroinvertebrate communities in mangrove forests. The first method was the collection of benthic macroinvertebrates using a $1 \times 1 \mathrm{~m}^{2}$ quadrat placed randomly in each site (with 6 replicates). Any macroinvertebrate fauna that were present on the ground within a quadrat were collected by hand. The specimens were then put in a plastic bag and preserved in $70 \%$ ethanol. The top layer of soil $(10 \mathrm{~cm})$ in a quadrat was also removed using a shovel and transferred to a plastic bag to investigate sedimentary invertebrate fauna. Sediments were taken to the laboratory, washed and sieved through a $0.5 \mathrm{~mm}$ sieve. Specimens of animals were separated and kept in a plastic bottle containing $70 \%$ ethanol for subsequent identification and counting. The second method was the collection of macroinvertebrate animals present onsite by hand by 2 people for $30 \mathrm{~min}$ as one sample (adapted from Macintosh et al., 2002). We randomly collected as many invertebrates as possible throughout each site. Specimens were kept in a plastic bag and preserved with $70 \%$ ethanol and identified in the laboratory up to the species level.

\section{Data analysis}

The data were averaged and presented as mean \pm standard deviation. An F-test at the 95\% confidence level was used to differentiate mangrove forest structure and water quality among studied sites (young, intermediate, mature and semi natural sites) using the SPSS 2013 software. We also used Primer (Plymouth routines in multivariate ecological research) 6 for MDS analysis (multidimensional scaling) to study the similarity or dissimilarity of physicochemical variables among sites. Cluster analysis was also applied to determine patterns in species composition and assemblages among sites. Data were transformed by square root and standardized. 


\section{Results}

The results revealed that mangrove plantation was a monoculture and the only species in the mangrove plantation used for charcoal production was Rhizophora apiculata (Table 1). In contrast, 5 species were found on the semi natural site consisting of $R$. apiculata, Xylocarpus granatum, Nypa fruticans, Cycas circinalis and Derris trifoliate. The heights of the trees differed significantly among sites. Trees aged 0-5 years were shortest $(5.12 \pm 0.49 \mathrm{~m})$ compared to trees aged $10-15$ years that were highest $(12.27 \pm 0.81 \mathrm{~m})$. The DBH ranged between 3.53 and $6.43 \mathrm{~cm}$ and also differed significantly between the younger mangrove site and the other sites. The DBH values increased with the age of the trees. The number of trees on each site varied from 11,111 to 27,778 trees per ha. The density decreased as the age of the trees increased.

Table 1. Detailed investigation of mangrove plantation at Yeesarn village, Samut Songkhram $(n=15)$

\begin{tabular}{lcccc}
\hline Parameter & \multicolumn{4}{c}{ Mangrove site } \\
\cline { 2 - 5 } & $\begin{array}{c}\text { Young } \\
\mathbf{0 - 5} \text { years }\end{array}$ & $\begin{array}{c}\text { Intermediate } \\
\mathbf{5 - 1 0} \text { years }\end{array}$ & $\begin{array}{c}\text { Mature } \\
\mathbf{1 0 - 1 5} \text { years }\end{array}$ & Semi natural \\
\hline Species & 1 & 1 & 1 & 5 \\
Height (m) & $5.12 \pm 0.49^{\mathrm{a}}$ & $8.75 \pm 0.53^{\mathbf{b}}$ & $12.27 \pm 0.81^{\mathbf{c}}$ & $11.01 \pm 3.32^{\mathbf{c}}$ \\
DBH $(\mathrm{cm})$ & $3.53 \pm 0.48^{\mathbf{a}}$ & $4.87 \pm 1.02^{\mathbf{b}}$ & $6.04 \pm 1.58^{\mathbf{b}}$ & $6.43 \pm 2.35^{\mathbf{b}}$ \\
Density & $27,778 \pm 4,006^{\mathbf{a}}$ & $14,444 \pm 4,006^{\mathbf{b}}$ & $11,111 \pm 3,333^{\mathbf{b}}$ & $17,778 \pm 3,334^{\mathbf{b}}$ \\
(trees/ha) & &
\end{tabular}

Remark: Mean values followed by different letters are significantly different $(p<0.05)$.

All studied creeks were relatively shallow (Table 2). Water quality analysis revealed that most values of physicochemical characteristics were comparable among sites and remained in good conditions. Temperature values were in the range of natural conditions and the $\mathrm{pH}$ values were neutral at all sites. Dissolved oxygen values varied between 3.45 and $4.57 \mathrm{mg} / \mathrm{l}$. Conductivity values corresponded well with the total dissolved solids and salinity indicating saline conditions in the studied areas. At all sites, nutrient concentrations were low. Total nitrogen concentrations were similar among sites but total phosphorus concentrations were detected only at the mature mangrove area and the semi natural site. Concentrations of chlorophyll a significantly differed among sites. The highest value of chlorophyll a was detected at the mature mangrove aged 10-15 years. BOD concentrations were somewhat low at all sites indicating low contamination of organic matter contents from human activities.

Table 2. Physicochemical characteristics of water at mangrove plantation sites in Yeesarn village $(n=6)$

\begin{tabular}{lcccc}
\hline Parameter & \multicolumn{4}{c}{ Mangrove site } \\
\cline { 2 - 5 } & $\begin{array}{c}\text { Young } \\
\mathbf{0 - 5} \text { years }\end{array}$ & $\begin{array}{c}\text { Intermediate } \\
\mathbf{5 - 1 0} \text { years }\end{array}$ & $\begin{array}{c}\text { Mature } \\
\mathbf{1 0 - 1 5} \text { years }\end{array}$ & Semi natural \\
\hline Water depth (m) & $1.4 \pm 0.1^{\mathrm{a}}$ & $1.3 \pm 0.6^{\mathrm{b}}$ & $0.7 \pm 0.05^{\mathrm{b}}$ & $1.0 \pm 0.1^{\mathrm{c}}$ \\
pH & $7.07 \pm 0.06^{\mathrm{a}}$ & $7.15 \pm 0.02^{\mathrm{a}, \mathrm{b}}$ & $7.33 \pm 0.12^{\mathrm{b}}$ & $6.96 \pm 0.05^{\mathrm{c}}$ \\
Temperature (c) & $31.25 \pm 0.17^{\mathrm{a}}$ & $30.75 \pm 0.37^{\mathrm{a}}$ & $32.0 \pm 1.47^{\mathrm{a}}$ & $30.83 \pm 0.29^{\mathrm{a}}$ \\
Transparency (cm) & $17.0 \pm 1.7^{\mathrm{a}}$ & $19.7 \pm 1.9^{\mathrm{a}, \mathrm{b}}$ & $24.3 \pm 5.4^{\mathrm{b}}$ & $19.5 \pm 1.6^{\mathrm{a}, \mathrm{b}}$ \\
DO (mg/l) & $4.57 \pm 0.54^{\mathrm{a}}$ & $4.06 \pm 0.37^{\mathrm{a}, \mathrm{b}}$ & $3.63 \pm 1.02^{\mathrm{a}, \mathrm{b}}$ & $3.45 \pm 0.61^{\mathrm{b}}$ \\
TDS (mg/l) & $7.48 \pm 1.09^{\mathrm{a}}$ & $6.98 \pm 0.20^{\mathrm{a}, \mathrm{b}}$ & $5.71 \pm 1.25^{\mathrm{b}}$ & $8.10 \pm 0.61^{\mathrm{a}, \mathrm{b}}$ \\
\hline
\end{tabular}




\begin{tabular}{lcccc}
\hline TSS (mg/l) & $158.16 \pm 19.42^{\mathrm{a}}$ & $99.64 \pm 11.56^{\mathrm{b}}$ & $83.61 \pm 23.31^{\mathrm{b}}$ & $89.69 \pm 27.53^{\mathrm{b}}$ \\
Conductivity & $13.65 \pm 1.58^{\mathrm{a}, \mathrm{b}}$ & $12.47 \pm 0.35^{\mathrm{a}}$ & $9.76 \pm 2.72^{\mathrm{a}}$ & $14.37 \pm 0.37^{\mathrm{b}}$ \\
(mS/cm) & $21.7 \pm 2.7^{\mathrm{a}}$ & $18.5 \pm 0.5^{\mathrm{a}}$ & $16.3 \pm 0.5^{\mathrm{b}}$ & $20.0 \pm 0.0^{\mathrm{c}}$ \\
Salinity (ppt) & $3.53 \pm 3.51^{\mathrm{a}}$ & $2.76 \pm 1.36^{\mathrm{a}}$ & $2.41 \pm 0.66^{\mathrm{a}}$ & $1.83 \pm 0.48^{\mathrm{a}}$ \\
TN $(\mathrm{mg} / \mathrm{l})$ & nd & nd & $0.17 \pm 0.40^{\mathrm{a}}$ & $0.17 \pm 0.40^{\mathrm{a}}$ \\
TP $(\mathrm{mg} / \mathrm{l})$ & $3.49 \pm 0.87^{\mathrm{a}}$ & $1.86 \pm 0.47^{\mathrm{b}}$ & $2.92 \pm 0.80^{\mathrm{a}, \mathrm{b}}$ & $2.34 \pm 0.45^{\mathrm{b}}$ \\
BOD (mg/l) & $9.53 \pm 2.29^{\mathrm{a}}$ & $5.67 \pm 0.85^{\mathrm{b}}$ & $22.73 \pm 5.70^{\mathrm{c}}$ & $6.69 \pm 1.36^{\mathrm{a}, \mathrm{b}}$ \\
\hline
\end{tabular}

Remark: Mean values followed by different letters are significantly different ( $p<0.05)$. nd is nondetectable.

The results of MDS analysis clearly distinguished similarities and dissimilarities in the general water quality among sites (Fig. 2). The water quality in the young and mature mangrove plantation sites was rather dissimilar as indicated by the sampling points that were far apart. On the other hand, the MDS analysis showed the similarity in the environmental variables between the intermediate mangrove plantation site and the semi natural mangrove forest.

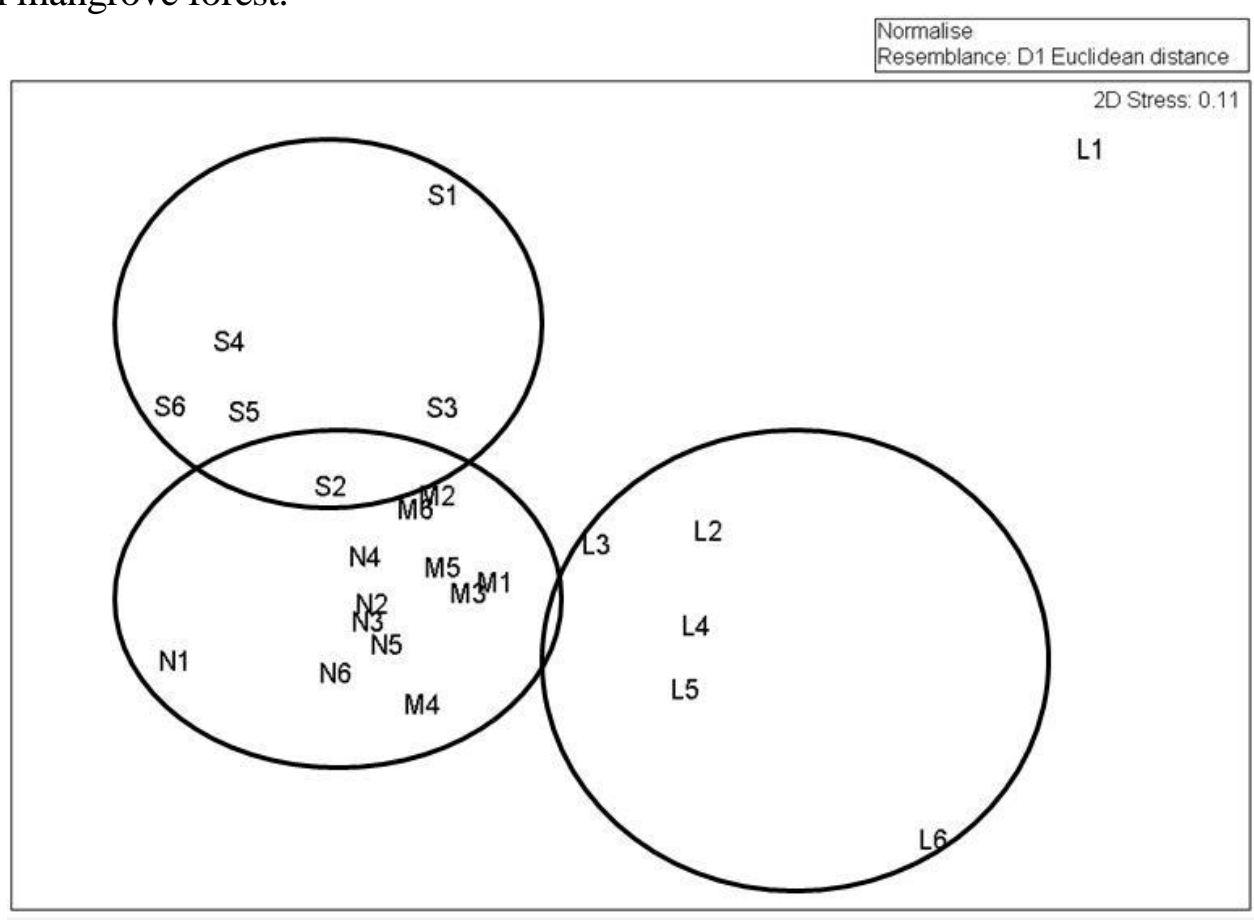

Figure 2. Multidimensional scaling analysis of environmental variables among studied sites $(S$ = young, $M=$ intermediate, $L=$ mature and $N=$ semi natural sites), the number represents sampling points (Stress $=0.11$ indicates fair goodness of fit).

The results of the biological studies showed that the species and densities of phytoplankton tended to be higher in the creek in the younger mangrove plantation sites compared with the older sites (Table 3). The most dominant species of phytoplankton present were Navicula sp., Gyrosigma sp. and Nitzschia sp. Similarly, the numbers of zooplankton were highest in the creek of the young mangrove site aged 0-5 years and were lower at the other older sites. However, the numbers of zooplankton species appeared to be similar among sites. Tintinnopsis gracilis, T. tubulosa and copepod nauplius were the main species recorded. 
The overall species of benthic macroinvertebrate animals (both collected by hand and by quadrat) increased with the age of the mangrove sites (Table 3). Common macroinvertebrates (snails) collected by hand belonged to the Family Elloblidae that were present at all sites. The main species were Melampus sp., Cassidula aurisfelis and Laemodonta punctigera. The abundances of macroinvertebrates collected by hand were relatively comparable among sites. However, the abundance of macroinvertebrates collected using a quadrat appeared to be greater in the older mangrove sites and lower in the younger mangrove areas. The main sedimentary species were in the Families Capitellidae and Spionidae. Other abundant animals collected using a quadrat included the Family Elloblidae (Melampus sp.) similar to those collected by hand.

Table 3. Species and abundances of biological resources in forest plantation sites of Yeesarn village, Samut Songkhram province $(n=6)$

\begin{tabular}{|c|c|c|c|c|}
\hline \multirow{2}{*}{$\begin{array}{l}\text { Biological } \\
\text { resource }\end{array}$} & \multicolumn{4}{|c|}{ Mangrove site } \\
\hline & $\begin{array}{c}\text { Young } \\
\text { 0-5 years }\end{array}$ & $\begin{array}{c}\text { Intermediate } \\
\text { 5-10 years }\end{array}$ & $\begin{array}{c}\text { Mature } \\
10-15 \\
\text { years }\end{array}$ & $\begin{array}{c}\text { Semi } \\
\text { natural }\end{array}$ \\
\hline \multicolumn{5}{|l|}{ Phytoplankton } \\
\hline Species & 22 & 11 & 15 & 8 \\
\hline Density (cell/l) & 1,737 & 584 & 584 & 218 \\
\hline \multicolumn{5}{|l|}{ Zooplankton } \\
\hline Species & 16 & 15 & 16 & 8 \\
\hline Density (ind./l) & 328 & 218 & 195 & 81 \\
\hline \multicolumn{5}{|l|}{$\begin{array}{l}\text { Benthic fauna } \\
\text { (by hand) }\end{array}$} \\
\hline Species & 8 & 9 & 13 & 12 \\
\hline $\begin{array}{l}\text { Density } \\
\text { (ind./30 min of } \\
\text { collection) }\end{array}$ & 159 & 160 & 157 & 138 \\
\hline \multicolumn{5}{|l|}{$\begin{array}{l}\text { Benthic fauna } \\
\text { (by quadrat) }\end{array}$} \\
\hline Species & 8 & 11 & 14 & 11 \\
\hline Density (ind. $/ \mathrm{m}^{2}$ ) & 20 & 33 & 49 & 43 \\
\hline
\end{tabular}

Cluster analysis shows distinct groups of benthic macroinvertebrates among sites (Fig. 3). The analysis revealed similar patterns of benthic communities collected by hand and by quadrat. Considering hand collection, there was a high level of similarity $(80 \%)$ of benthic macroinvertebrate communities between mature mangrove (L) and semi natural mangrove $(\mathrm{N})$ sites. There was also similarity $(76.5 \%)$ in the species composition of benthic macroinvertebrates between the young $(\mathrm{S})$ and intermediate $(\mathrm{M})$ mangrove plantation sites. Two groups of benthic macroinvertebrates collected by quadrat were also detected at the high level of similarity $(76 \%)$ between the mature mangrove (L) and the semi natural mangrove $(\mathrm{N})$ sites and there was $66 \%$ similarity $(76.5 \%)$ in the benthic macroinvertebrate composition of the young (S) and intermediate (M) mangrove plantation sites. 


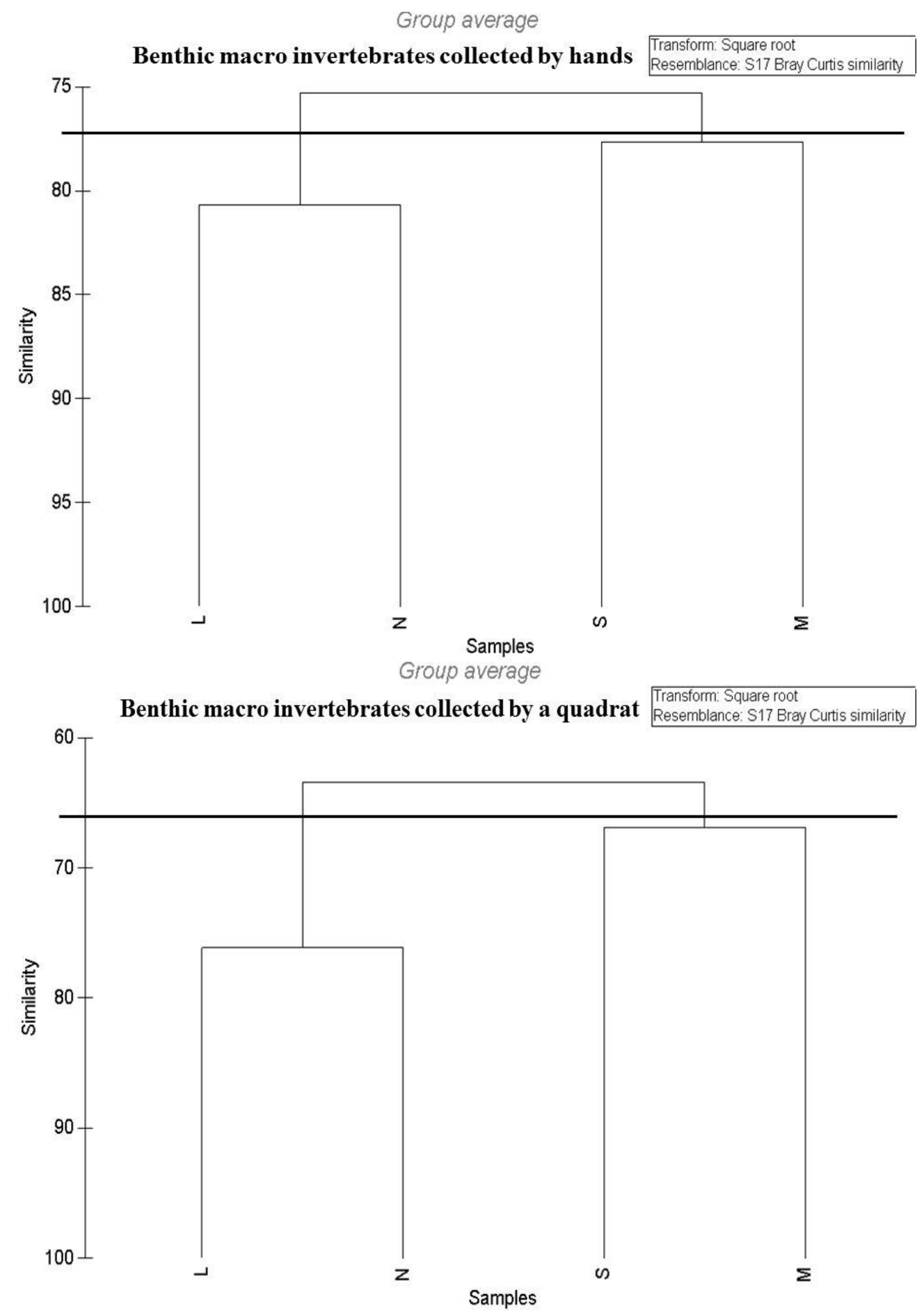

Figure 3. Dendrogram of cluster analysis showing 2 groups of similarity of benthic macroinvertebrates among mangrove sites ( $S=$ young, $M=$ intermediate, $L=$ mature and $N=$ semi natural sites).

\section{Discussion}

Regarding mangrove plantation structure, our results were rather consistent with other studies (Hassan, 2006; Kridiborworn et al., 2012). The recent study conducted in 2012 reported that Rhizophora apiculata was the main mangrove species planted for 
charcoal production in Yeesarn village. An average density of mangrove in plantation sites recorded in 2012 was around 22,089 trees/ha similar to the density of the mangrove plantation at age $0-5$ years in our study $(27,778$ trees/ha). The average height $(10-11 \mathrm{~m})$ and DBH $(3-4 \mathrm{~cm})$ of mangrove trees at the harvest age $(9-12$ years) from the previous study (Krindiborworn et al., 2012) were also comparable with the current study. Rhizophora apiculata appears to be a suitable species for charcoal production in Yeesarn village because it grows well in the estuarine and intertidal environment as well as having high quality in terms of the carbon content and calorific value (Krindiborworn et al., 2012).

Water quality in the creeks of all mangrove sites was good and suitable for aquatic organisms. The results of the present study were also similar to other studies in the region (Gandaseca et al., 2011; Jitthaisong et al., 2012). The water was salty as it is a specific characteristic of an estuarine environment. Phosphorus concentrations were rather low at most sampling stations and the nitrogen concentrations were comparable among sites. BOD concentrations were also low. Mangrove plantations are usually located far from local community settlements or are around the edge of the land (transition zone) and therefore are less impacted by household waste and pollution. The present study is in contrast with Tripathy et al. (2005) who found high concentrations of nutrients in an Indian mangrove ecosystem due to adjacent sources of nutrient. In addition, in the current study, the water quality appeared not to be affected much by mangrove sites since during data collection, as all mangrove sites were not inundated due to a low tide period.

The results of the biodiversity studies at the mangrove sites revealed interesting findings. The phytoplankton population and density appeared to be higher at the younger mangrove plantation site compared with the mature-aged sites. It was likely due to shading created by the canopy at the older-aged mangrove sites which reduced the light availability in the creeks and thus suppressed the growth of phytoplankton. Communities of zooplankton were also high and seemed to correspond well with the phytoplankton population.

The community of invertebrate animals changed with the age of the mangrove forest stand similar to Ashton et al. (2003). In particular, species of benthic macroinvertebrate fauna (collected by hand) tended to increase more at the mature mangrove sites than at the younger plantation sites. The present study of common macroinvertebrates recorded was also consistent with Macintosh et al. (2012) who reported that snails of the families Neritidae and Ellobiidae were the most abundant and common molluscs in mangrove forests. The communities of benthic and sedimentary invertebrates (collected by quadrat) were present in high numbers in the mature plantation mangrove forest and semi natural areas. This could be explained by the fact that the mature mangrove plantation forests provided rich and crucial food sources for benthic macroinvertebrate communities. Long colonization and assemblages of benthic mancro invertebrates in the mature mangrove plantations could also account for the greater numbers of animal species that we recorded. In the young plantation forests, it may take several more years for macroinvertebrates to colonize and establish the population. From observation, the plantation trees at the younger sites may also create a drier soil environment due to light penetration through the open canopy, thus being less suitable for some animals such as molluscs and annelids compared to the wetter condition in the older-aged plantation forests with tall trees having a large closed canopy. The low frequency of inundated environmental conditions may also be responsible for the presence or absence of some 
mangrove fauna (Ashton et al., 2003). Several studies have indicated that different groups of benthic animals prefer different environments; for example, fiddler crabs prefer semi-open mangrove habitat with some light penetration while sesarmid crabs prefer a more closed canopy created by mature forest stands (Macintosh et al., 1984; 2012, Ashton et al., 2003).

\section{Conclusions}

In conclusion, this study showed differences in the community structure of intertidal benthic macroinvertebrates between the younger mangrove plantation sites and the mature old-aged mangrove forests. It could also be stated that benthic macroinvertebrate communities and populations in mangrove plantation areas have developed through time and the older the mangrove forests, the higher biodiversity and abundances of the benthic fauna. Accordingly, our findings support the fact that apart from having high economic value for charcoal production, mangrove plantation forests also play an important role in estuarine ecosystems since mangrove plantation forests, especially mature forest stands, provide suitable habitats and food sources for many species, especially molluscs and crustaceans.

Acknowledgements. We are grateful to the Kasetsart University Research and Development Institute (KURDI) for financially support this research under the main project of "Assessing the potential of mangrove forest for renewable energy source: quality and energy yield, socio-economics and environment".

\section{REFERENCES}

[1] Andradi-Brown, D.A., Howe, C., Mace, G.M., Knight, A.T. (2013): Do mangrove forest restoration or rehabilitation activities return biodiversity to pre-impact levels? Environmental Evidence Journal 2(20): 1-8.

[2] Ashton, E.C., Hogarth, P.J., Macintosh, D.J. (2003): A comparison of brachyuran crab community structure at four mangrove locations under different management systems along the Melaka Straits-Andaman Sea coast of Malaysia and Thailand. Estuaries 26(6): 1461-1471.

[3] Bandaranayake, W.M. (1998): Traditional and medicinal uses of mangroves. Mangroves and Salt Marshes 2(3): 133-148.

[4] Chayaburakul, K., Nash, G., Pratanpipat, P., Sriurairatana, S., Withyachumnarnkul, B. (2004): Multiple pathogens found in growth-retarded black tiger shrimp Penaeus monodon cultivated in Thailand. - Dis Aquat Org 60: 89-96.

[5] Chaiyasarn, W. (2007): Sustainability of mangrove plantation in Yeesarn community, Amphawa District, Samut Songkhram province. Master Thesis. Kasetsart University. Thailand. $101 \mathrm{p}$.

[6] Dierberg, F.E., Kiattisimkul, W. (1996): Issues, impacts, and implications of shrimp aquaculture in Thailand. - Environmental Management 20(5): 649-666.

[7] Flegel, T.W. (1997): Major viral diseases of the black tiger prawn (Penaeus monodon) in Thailand. - World Journal of Microbiology and Biotechnology 13(4): 433442.

[8] Gandaseca, S., Rosli, N., Ngayop, J., Arianto, C.I. (2011): Status of water quality based on the physico-chemical assessment on river water at wildlife sanctuary Sibuti mangrove forest, Miri Sarawak. - American Journal of Environmental Sciences 7 (3): 269-275. 
[9] Hassan, K. (2006): Management of private mangrove (Rhizophora apiculata) plantation for charcoal production at Yeesarn Sub-District, Samut Songkram province. Master Thesis. Kasetsart University. Thailand.

[10] Jitthaisong, O., Dhanmanonda, P., Chunkao, K., Teejuntuk, S. (2012): Water quality from mangrove forest: the King's Royally Initiated Laem Phak Bia environmental research and development project, Phetchaburi province, Thailand. - Modern Applied Science 6(8): 1-8.

[11] Kaplowitz, M.D. (2001): Assessing mangrove products and services at the local level: the use of focus groups and individual interviews. - Landscape and Urban Planning 56(1-2): 53-60.

[12] Kathiresan, K. (2012) Importance of mangrove ecosystem. - International Journal of Marine Science 2(10): 70-89.

[13] Kathiresan, K. (2012): Importance of mangrove forests of India. - Journal of Coastal Environment 1(1): 11-26.

[14] Kridiborworn, P., Chidthaisong, A., Yuttitham, M., Tripetchkul, S. (2012): Carbon sequestration by mangrove forest planted specifically for charcoal production in Yeesarn, Samut Songkram. - Journal of Sustainable Energy \& Environment 3: 87-92.

[15] Macintosh, D. J. (1984): Ecology and productivity of Malaysian mangrove crab populations (Decapoda: Brachyura).- In: Soepadmo, E., Rao, A. N., Macintosh, D. J. (eds.) Proceedings of the Asian Symposium on Mangrove Environment, Research and Management. University of Malaya and UNESCO, pp. 354-77.

[16] Macintosh, D.J., Ashton, E.C., Havanon, S. (2012): Mangrove rehabilitation and intertidal biodiversity: a study in the Ranong mangrove ecosystem, Thailand. - Estuarine, Coastal and Shelf Science 55: 331-345.

[17] Osti, R., Tanak, S., Tokioka, T. (2009): The importance of mangrove forest in tsunami disaster mitigation. - Disasters 33(2): 203-213

[18] Primavera, J. H. (1993): A critical review of shrimp pond culture in the Philippines. Reviews in Fisheries Science 1: 151-201.

[19] Ronnback, P. (1999): The ecological basis for economic value of seafood productionsupported by mangrove ecosystems. - Ecological Economics 29(2): 235-252.

[20] Tripathy, S.C., Ray, A.K., Patra, S., Sarma, V.V. (2005): Water quality assessment of Gautami - Godavari mangrove estuarine ecosystem of Andhra Pradesh, India during September 2001. - Journal of Earth System Science 114(2): 185-190.

[21] Tontaweewong, A. (2000): Continuity and change of Rhizophora charcoal burning in "sustainable economic" pattern at Yeesarn Village. Master Thesis. Kasetsart University. Thailand. 101 p. (in Thai with English abstract).

[22] Vo., Q.T., Kuenzer, C., Minh Vo, Q., Moder, F., Oppelt, N. (2012): Review of valuation methods for mangrove ecosystem services. - Ecological Indicators 23: 431-446.

[23] Wafar, S., Untawale, A.G. and Wafar, M. (1997): Litter fall and energy flux in a mangrove ecosystem. - Estuarine, Coastal and Shelf Science 44(1): 111-124. 


\section{APPENDIX}

Table A1. A list of invertebrate species collected by using a quadrat

\begin{tabular}{|l|}
\hline Phylum Annelida \\
\hline Class Polychaeta \\
\hline Family Capitellidae \\
\hline Mediomastus sp. \\
\hline Family Spionidae \\
\hline Prionospio sp. \\
\hline Oligochaeta \\
\hline Phylum Sipuncula \\
\hline Sipunculus sp. \\
\hline Phylum Arthropoda \\
\hline Class Crustacea \\
\hline Family Amphipoda \\
\hline Gammaridea \\
\hline Family Alpheidae \\
\hline Alpheus euphrosyne \\
\hline Family Grapsidae \\
\hline Episesarma mederi \\
\hline Sesarma (Chiromantes) eumolpe \\
\hline Sesarma mederi \\
\hline Family Ocypodidae \\
\hline Macrophthalmus teschi \\
\hline Uca forcipata \\
\hline Phylum Mollusca \\
\hline Family Gastropoda \\
\hline Assiminea sp . \\
\hline Family Elloblidae \\
\hline Melampus siamesis \\
\hline Melampus sp. \\
\hline Cassidula aurisfelis \\
\hline Laemodonta punctigera \\
\hline Family Neritidae \\
\hline Neritina violacea \\
\hline Family Mytllidae \\
\hline Modiolus philippinarum \\
\hline Family Potamiddae \\
\hline Cerithium sp. \\
\hline Family Dounacidae \\
\hline Donax sp. \\
\hline
\end{tabular}

Table A2. A list of invertebrate species collected by hands

\begin{tabular}{|l|}
\hline Phylum Annelida \\
\hline Class Polychaeta \\
\hline Family Capitellidae \\
\hline Mediomastus sp. \\
\hline Family Spionidae \\
\hline Prionospio sp. \\
\hline Oligochaeta \\
\hline Phylum Sipuncula \\
\hline Sipunculus sp. \\
\hline Phylum Arthropoda \\
\hline Class Crustacea \\
\hline Family Amphipoda \\
\hline Gammaridea \\
\hline Family Alpheidae \\
\hline Alpheus euphrosyne \\
\hline Family Grapsidae \\
\hline Episesarma mederi \\
\hline Sesarma (Chiromantes) eumolpe \\
\hline Sesarma mederi \\
\hline Family Ocypodidae \\
\hline Macrophthalmus teschi \\
\hline Uca forcipata \\
\hline Phylum Mollusca \\
\hline Family Gastropoda \\
\hline Assiminea sp. \\
\hline Family Elloblidae \\
\hline Melampus siamesis \\
\hline Melampus sp. \\
\hline Cassidula aurisfelis \\
\hline Laemodonta punctigera \\
\hline Family Neritidae \\
\hline Neritina violacea \\
\hline Family Mytllidae \\
\hline Modiolus philippinarum \\
\hline Family Potamiddae \\
\hline Cerithium sp. \\
\hline Family Dounacidae \\
\hline Donax sp. \\
\hline
\end{tabular}

